Steven A. Hardy, PhD

Emma L. Blakely, PhD, FRCPath

Andrew I. Purvis, PhD

Mariana C. Rocha, PhD

Syeda Ahmed, BSc

Gavin Falkous, MPhil

Joanna Poulton, DM

Michael R. Rose, MD, FRCP

Olivia O'Mahony, MRCPCH, FRCPI

Niamh Bermingham, FRCPath

Charlotte F. Dougan, MD, FRCP

Yi Shiau Ng, MRCP

Rita Horvath, MD, PhD

Doug M. Turnbull, PhD, FRCP

Grainne S. Gorman, $\mathrm{PhD}$, MRCP

Robert W. Taylor, PhD, FRCPath

Neurol Genet

2016;2:e82; doi: 10.1212/ NXG.0000000000000082

Supplemental data at Neurology.org/ng

\section{PATHOGENIC mIDNA MUTATIONS CAUSING MITOCHONDRIAL MYOPATHY: THE NEED FOR MUSCLE BIOPSY \\ OPEN}

Pathogenic mitochondrial tRNA (mt-tRNA) gene mutations represent a prominent cause of primary mitochondrial DNA (mtDNA)-related disease despite accounting for only $5 \%-10 \%$ of the mitochondrial genome. ${ }^{1,2}$ Although some common mt-tRNA mutations, such as the m.3243A $>$ G mutation, exist, the majority are rare and have been reported in only a small number of cases. ${ }^{3}$ The MT-TP gene, encoding mt-tRNA ${ }^{\text {Pro }}$, is one of the less polymorphic mt-tRNA genes, and only 5 MT-TP mutations have been reported as a cause of mitochondrial muscle disease to date (table e-1 at Neurology.org/ng, P6-10). We report 5 patients with myopathic phenotypes, each harboring different pathogenic mutations in the MT-TP gene, highlighting the importance of MT-TP mutations as a cause of mitochondrial muscle disease and the requirement to study clinically relevant tissue.

Methods. All patients were referred to our specialist mitochondrial laboratory in Newcastle upon Tyne, UK. Diagnostic muscle biopsies were analyzed by standard histopathologic and biochemical techniques and a quadruple immunofluorescent assay to assess the expression of mitochondrial complex I and complex IV subunits. ${ }^{4}$ DNA was extracted using standard protocols; sequencing of the entire mitochondrial genome (GenBank Accession Number NC_012920.1) was undertaken using muscle DNA. Pyrosequencing was used to quantitatively assess mtDNA mutation heteroplasmy levels in available tissues and in laser-captured individual cytochrome $c$ oxidase $(\mathrm{COX})$-positive and COX-deficient fibers. ${ }^{2}$

Results. We identified 5 adult patients with mitochondrial disease due to mutations in the MT-TP gene; their clinical, histochemical, and genetic data are summarized in table e-1. Histopathologic analysis of muscle biopsies from all 5 patients revealed marked mitochondrial pathology in the form of a mosaic pattern of COX deficiency (figure 1A), which ranged from $\sim 16 \%$ COX-deficient fibers in patient 3 up to $>80 \%$ COX-deficient fibers from patients 2 and 5. COX-deficient ragged-red fibers were noted in all patients to varying degrees, although strongly succinate dehydrogenase-reactive blood vessels were not reported (figure 1A). Quantitative fluorescence-based immunohistochemistry confirmed decreased levels of both complex I (NDUFB8) and complex IV (COX-I) subunits, in accordance with an underlying disorder of mitochondrial translation (figure e-1).

Sequencing of the entire mitochondrial genome identified candidate MT-TP gene mutations at evolutionarily conserved positions in all 5 patients (figure 1 , $\mathrm{A}$ and $\mathrm{B}$; figure e-2). The m.15975T $>\mathrm{C}$ mutation $^{5}$ and m.16002T $>\mathrm{C}$ mutation $^{6}$ in patients 1 and 3 , respectively, were previously reported, while those in patient $2(\mathrm{~m} .15998 \mathrm{~A}>\mathrm{T})$, patient $4(\mathrm{~m} .16015 \mathrm{~T}>\mathrm{C})$, and patient 5 (m.16021_16022del) were novel. In all cases, the highest mutation load was detectable in muscle, varying from $25 \%$ in patient 3 to $>95 \%$ in patients 2 and 5 (table e-1). Screening of additional tissues was also performed; patients 1, 2, and 3 showed restricted expression of the $M T-T P$ mutation to muscle, while patients 4 and 5 showed a hierarchical mutation segregation pattern (table e-1). Single muscle fiber segregation studies demonstrated statistically significant higher mutation levels in COX-deficient fibers compared with COX-positive fibers, thus confirming pathogenicity of each MT-TP mutation (figure 1C; table e-2).

Discussion. We report 5 adult patients with mitochondrial disease due to different mutations in the MT-TP gene with a predominantly myopathic phenotype. Ptosis (+/- progressive external ophthalmoplegia), proximal myopathy, and marked perceived fatigue appear to be salient features. In each case, the marked degree of COX deficiency and downregulation of both complex I and complex IV subunits in muscle was strongly suggestive of a defect in mitochondrial translation and entirely in keeping with an mt-tRNA mutation. To date, only 5 patients have been reported, each with different MT-TP mutations, and variable clinical features have been observed including ataxia, deafness, dilated cardiomyopathy, myoclonic epilepsy with ragged-red fibers-like disease, and retinitis pigmentosa; a myopathic phenotype is reported in all cases (table e-1). 

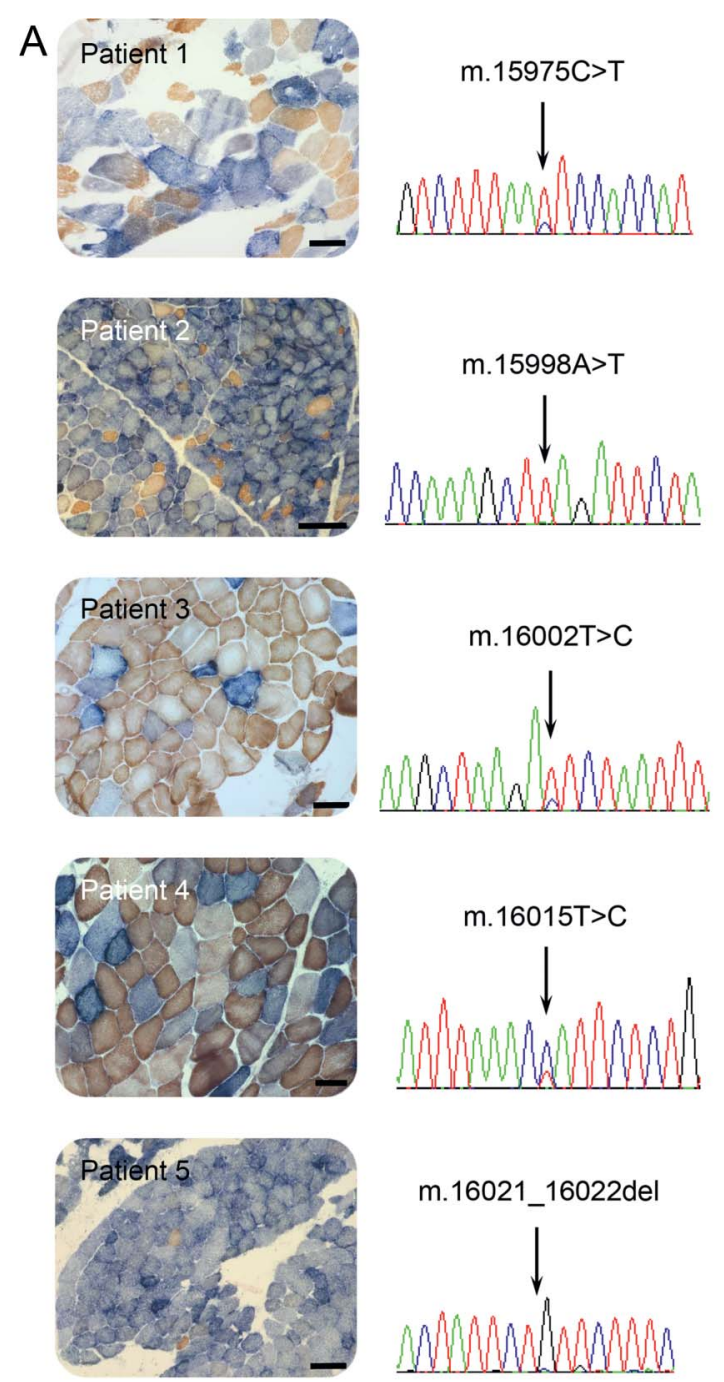

(A) Sequential COX-succinate dehydrogenase histochemistry demonstrating a mosaic pattern of COX deficiency in all patient muscle samples (COX-deficient fibers are blue, COX-positive fibers are brown); note the presence of COX-deficient ragged-red fibers in each of the 5 biopsies (scale bar = $100 \mu \mathrm{m})$. Sequence electropherograms showing the relevant MT-TP mutation for each patient are also included. (B) Schematic representation of the cloverleaf structure of the mt-tRNAPro molecule and the corresponding location of the 5 pathogenic mutations. Each mutation occurs in a different stem of the mt-tRNA ${ }^{\text {Pro }}$ molecule. The affected position and the substitution that occurs are highlighted in bold. (C) Single muscle fiber mutation load segregation. The graph shows the mutation load measured in individual COX-positive (closed circles) and COX-deficient fibers (open circles) laser-microdissected from muscle biopsies of the 5 patients. In each case, the candidate MT-TP mutation segregates with the biochemical (COX) defect in single muscle fibers.

Patients 1, 2, and 3 showed restricted expression of their MT-TP mutations to muscle, strongly indicative of a de novo mutational event, ${ }^{7}$ whereas patients 4 and 5 showed a hierarchical segregation pattern as observed in many pathogenic mtDNA mutations. Screening of maternal samples was undertaken for patients 2,4 , and 5 , with maternal inheritance being confirmed in patient 4 only. Of note, only one of the previous studies demonstrated maternal inheritance of the MT-TP mutation, with 4 of the remaining studies also reporting apparent or likely de novo mutational events.

Single muscle fiber segregation studies remain the gold standard test to confidently establish pathogenicity of novel mtDNA variants. Although the m. $15975 \mathrm{~T}>\mathrm{C}^{5}$ and $\mathrm{m} .16002 \mathrm{~T}>\mathrm{C}^{6}$ mutations have been reported previously, functional studies were not undertaken to confirm pathogenicity. Subsequent studies in muscle biopsies of all 5 patients confirm that mutation loads segregated with the mitochondrial histochemical defects in muscle (figure 1C; table e-2), powerfully illustrating an ongoing requirement to access pathologically relevant tissue-skeletal muscle-to support the investigation and diagnosis of patients with mitochondrial myopathy, even in the current era of high-throughput next-generation sequencing technologies.

From the Wellcome Trust Centre for Mitochondrial Research, Institute of Neuroscience (S.A.H., E.L.B., A.I.P., M.C.R., S.A., G.F., Y.S.N., D.M.T., G.S.G., R.W.T.), The Medical School, Institute of Genetic Medicine (R.H.), Newcastle University; 
Nuffield Department of Obstetrics and Gynaecology (J.P.), University of Oxford; Department of Neurology (M.R.R.), King's College Hospital NHS Foundation Trust, London; Departments of Neurology and Neuropathology (O.O., N.B.), Cork University Hospital, Ireland; and The Walton Centre for Neurology and Neurosurgery (C.F.D.), Liverpool, UK.

Author contributions: S.A.H. analysis and interpretation of data, acquisition of data, statistical analysis, and writing of the manuscript. E.L.B. analysis and interpretation of data. A.I.P. analysis and interpretation of data. M.C.R. analysis and interpretation of data. S.A: analysis and interpretation of data. G.F: analysis and interpretation of data. J.P: acquisition of data and clinical investigations. M.R.R: acquisition of data and clinical investigations. O.O'M: acquisition of data and clinical investigations. N.B: analysis and interpretation of data. C.F.D: acquisition of data and clinical investigations. Y.S.N: acquisition of data and clinical investigations. R.H: acquisition of data and clinical investigations. D.M.T: critical revision of the manuscript for important intellectual content. G.S.G: study concept and design, critical revision of the manuscript for important intellectual content, study supervision and coordination. R.W.T: study concept and design, critical revision of the manuscript for important intellectual content, study supervision and coordination, obtaining funding.

Acknowledgment: The clinical and diagnostic mitochondrial services in both Newcastle upon Tyne and Oxford are funded by the UK NHS Highly Specialised Service for Rare Mitochondrial Disorders of Adults and Children.

Study funding: This study was funded by a Wellcome Trust Strategic Award (096919Z/11/Z).

Disclosure: Dr. Hardy, Dr. Blakely, Dr. Purvis, Dr. Rocha, Ms. Ahmed, and Mr. Falkous report no disclosures. Dr. Poulton is supported by the Medical Research Council (UK) (MR/J010448/1), Wellcome Trust (0948685/Z/10/Z), and the UK NHS Highly Specialised Service for Rare Mitochondrial Disorders of Adults and Children. Dr. Rose serves on the editorial board of Cochrane Collaboration; and has received research support from the European Union, NIH, the Association Francais contre Myologie (AFM), and Myositis UK. Dr. O'Mahony and Dr. Bermingham report no disclosures. Dr. Dougan has received travel funding/speaker honoraria from GRIFOLS; and has made small financial donations to the Walton Centre. Dr. Ng reports no disclosures. Dr. Horvath is supported by the Medical Research Council (UK) (G1000848) and the European Research Council (309548). Dr. Turnbull is supported by the Wellcome Trust Centre for Mitochondrial Research (096919Z/ 11/Z), the MRC Centre for Translational Research in Neuromuscular Disease Mitochondrial Disease Patient Cohort (UK) (G0800674), the Lily Foundation and the UK NIHR Biomedical Research Centre for Ageing and Age-related disease award to the Newcastle upon Tyne Foundation Hospitals NHS Trust.
Dr. Gorman is supported by the UK NIHR Biomedical Research Centre for Ageing and Age-related disease award to the Newcastle upon Tyne Foundation Hospitals NHS Trust; and is an employee of the University of Newcastle. Dr. Taylor is supported by the Wellcome Trust Centre for Mitochondrial Research (096919Z/11/Z), the MRC Centre for Translational Research in Neuromuscular Disease Mitochondrial Disease Patient Cohort (UK) (G0800674), the Lily Foundation, and the UK NIHR Biomedical Research Centre for Ageing and Age-related disease award to the Newcastle upon Tyne Foundation Hospitals NHS Trust. Go to Neurology.orging for full disclosure forms. The Article Processing Charge was paid by Newcastle University.

This is an open access article distributed under the terms of the Creative Commons Attribution License 4.O (CC BY), which permits unrestricted use, distribution, and reproduction in any medium, provided the original work is properly cited.

Received March 22, 2016. Accepted in final form May 16, 2016.

Correspondence to Prof. Taylor: robert.taylor@ncl.ac.uk

1. Yarham JW, Elson JL, Blakely EL, McFarland R, Taylor RW. Mitochondrial tRNA mutations and disease. Wiley Interdiscip Rev RNA 2010;1:304-324.

2. Blakely EL, Yarham JW, Alston CL, et al. Pathogenic mitochondrial tRNA point mutations: nine novel mutations affirm their importance as a cause of mitochondrial disease. Hum Mutat 2013;34:1260-1268.

3. Ruiz-Pesini E, Lott MT, Procaccio V, et al. An enhanced MITOMAP with a global mtDNA mutational phylogeny. Nucleic Acids Res 2007;35:D823-D828.

4. Rocha MC, Grady JP, Grünewald A, et al. A novel immunofluorescent assay to investigate oxidative phosphorylation deficiency in mitochondrial myopathy: understanding mechanisms and improving diagnosis. Sci Rep 2015;5: 15307. doi: 10.1038/srep150372.

5. Da Pozzo P, Cardaiolo E, Malfatti E, et al. A novel mutation in the mitochondrial tRNA(Pro) gene associated with late-onset ataxia, retinitis pigmentosa, deafness, leukoencephalopathy and complex I deficiency. Eur J Hum Genet 2009; 17:1092-1096.

6. Seneca S, Ceuterik-De Groote C, Van Coster R, De Meirleir L. A novel mitochondrial transfer RNA proline mutation. J Inherit Metab Dis 2000;23:853-854.

7. Elson JL, Swalwell H, Blakely EL, McFarland R, Taylor RW, Turnbull DM. Pathogenic mitochondrial tRNA mutations-which mutations are inherited and why? Hum Mutat 2009;30:E984-E992. 


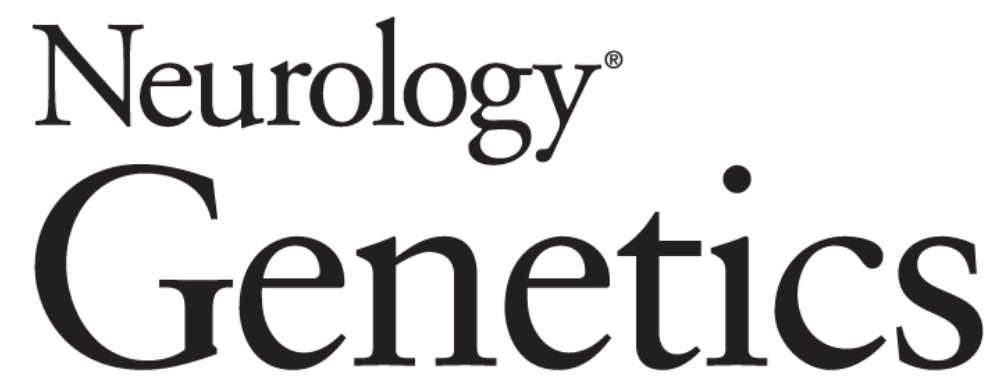

Pathogenic mtDNA mutations causing mitochondrial myopathy: The need for muscle biopsy

Steven A. Hardy, Emma L. Blakely, Andrew I. Purvis, et al. Neurol Genet 2016;2;

DOI 10.1212/NXG.0000000000000082

This information is current as of June 23, 2016

Neurol Genet is an official journal of the American Academy of Neurology. Published since April 2015, it is an open-access, online-only, continuous publication journal. Copyright ( 2016 American Academy of Neurology. All rights reserved. Online ISSN: 2376-7839.

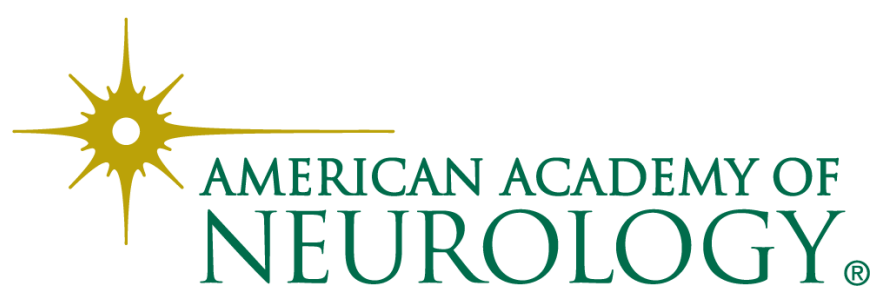




\section{Updated Information \&} Services

\section{Supplementary Material}

References

Subspecialty Collections

Permissions \& Licensing

Reprints including high resolution figures, can be found at: http://ng.neurology.org/content/2/4/e82.full.html

Supplementary material can be found at: http://ng.neurology.org/content/suppl/2016/06/23/2.4.e82.DC1

This article cites 7 articles, 0 of which you can access for free at: http://ng.neurology.org/content/2/4/e82.full.html\#\#ref-list-1

This article, along with others on similar topics, appears in the following collection(s):

\section{Mitochondrial disorders}

http://ng.neurology.org//cgi/collection/mitochondrial_disorders Mitochondrial disorders; see Genetics/Mitochondrial disorders http://ng.neurology.org//cgi/collection/mitochondrial_disorders_see_ge netics-mitochondrial_disorders

Muscle disease

http://ng.neurology.org//cgi/collection/muscle_disease

Information about reproducing this article in parts (figures,tables) or in its entirety can be found online at:

http://ng.neurology.org/misc/about.xhtml\#permissions

Information about ordering reprints can be found online: http://ng.neurology.org/misc/addir.xhtml\#reprintsus

Neurol Genet is an official journal of the American Academy of Neurology. Published since April 2015, it is an open-access, online-only, continuous publication journal. Copyright ( 2016 American Academy of Neurology. All rights reserved. Online ISSN: 2376-7839.

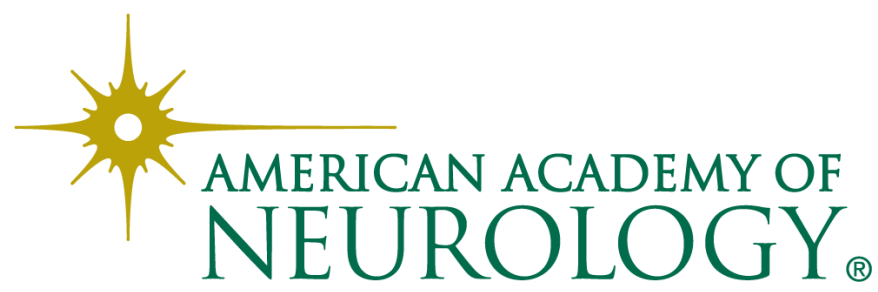

